\title{
„Rés a pajzson” - a pajzsmirigy modern képalkotó vizsgálata multidiszciplináris szemszögből
}

\author{
Palásti Péter dr. ${ }^{1}$ - Zombori Tamás dr. ${ }^{2}$ - Kaiser László dr. ${ }^{2}$ \\ Magony Sándor dr. ${ }^{3}$ - Kakuja Flóra oh. ${ }^{1}$ \\ Vörös András dr. ${ }^{2}$. Morvay Zita dr. ${ }^{1}$ - Kincses Zsigmond Tamás dr. ${ }^{1}$ \\ Palkó András dr. ${ }^{1}$. Fejes Zsuzsanna dr. ${ }^{1}$ \\ 'Szegedi Tudományegyetem, Általános Orvostudományi Kar, Radiológiai Klinika, Szeged \\ ${ }^{2}$ Szegedi Tudományegyetem, Általános Orvostudományi Kar, Patológiai Intézet, Szeged \\ ${ }^{3}$ Szegedi Tudományegyetem, Általános Orvostudományi Kar, I. Belgyógyászati Klinika, Szeged
}

\begin{abstract}
A pajzsmirigy az első szervek közé tartozik, melyek megjelenítésében, betegségeinek felfedezésében az ultrahangdiagnosztikának fontos szerepe van. A pajzsmirigybetegségek a lakosság jelentős részét érintik, és a technika fejlődésével egyre több pajzsmirigyeltérés, göb kerül felfedezésre. A pajzsmirigy rosszindulatú folyamatainak nincs egy bizonyos specifikus jele, viszont az ultrahangkép alapján meghatározhatók a malignitásra gyanús eltérések. Erre az elmúlt években több összefoglaló rendszer is született. Jelen összefoglaló tanulmányunknak az a célja, hogy bemutassuk a pajzsmirigy ultrahangdiagnosztikájának fejlődését; összehasonlítsuk az egyes leletezési rendszereket, úgymint TIRADS, EU-TIRADS, K-TIRADS, melyek célja a feltehetőleg rosszindulatú göbök kiszúrése, azonosítása a mindennapi rutinmunka során; vizsgáljuk a különböző rendszerek kapcsolatát a patológia által használt Bethesda-pontrendszerrel. Az ultrahangvizsgálat megfelelő értékelése, a pontrendszerek ismerete segíthet a pajzsmirigygöb differenciáldiagnózisában, a követési frekvencia meghatározásában, csökkentheti az aspirációs citológiák számát, ezzel támogatva a klinikai döntéshozatalt.
\end{abstract}

Orv Hetil. 2021; 162(14): 530-541.

Kulcsszavak: pajzsmirigy, ultrahangvizsgálat, aspirációs citológia

\section{"Gap in the shield" - imaging of the thyroid gland from the multidisciplinary perspective}

The thyroid gland was one of the first organs, the ultrasound (US) examination of which has played an important role. The thyroid diseases affect a large part of the population, and with the development of imaging technology, more and more thyroid abnormalities, nodules and malignant lesions are being discovered. There are no specific signs of thyroid cancer, but the suspicious signs could be determined by US. In recent years, several systems have been developed. The aim of our review is to demonstrate the development of US diagnostics of the thyroid gland; to compare the different reporting systems, such as TIRADS, EU-TIRADS, K-TIRADS, which should help to identify the questionable lesions in the daily routine work. We examine the relationship between the different US systems and the Bethesda point score used by pathologists. The literature review shows that the US examination supports the clinical decisions, helps to select, who should have a fine-needle biopsy, and allows to determine the frequency of follow-up. The number of unnecessary fine-needle biopsies could be reduced, too. Our paper is part of a bigger research, the ethical license number is $23 / 2020$, University of Szeged.

Keywords: thyroid gland, ultrasound, fine-needle aspiration biopsy

Palásti P, Zombori T, Kaiser L, Magony S, Kakuja F, Vörös A, Morvay Z, Kincses ZsT, Palkó A, Fejes Zs. [“Gap in the shield" - imaging of the thyroid gland from the multidisciplinary perspective]. Orv Hetil. 2021; 162(14): $530-541$.

(Beérkezett: 2020. július 22.; elfogadva: 2020. augusztus 26.) 


\section{Rövidítések}

AACE $=$ (American Association of Clinical Endocrinologists $)$ Amerikai Klinikai Endokrinológusok Egyesülete; ACE = (American College of Endocrinology) Amerikai Endokrinológiai Kollégium; ACR-TIRADS = (American College of Radiology - Thyroid Imaging, Reporting and Data System) Amerikai Radiológiai Kollégium - Pajzsmirigy Képalkotó Leletezési Adatrendszer; AI-TIRADS $=($ Artificial Intelligence - Thyroid Imaging, Reporting and Data System) Mesterséges Intelligencia - Pajzsmirigy Képalkotó Leletezési Adatrendszer; AME = (Associazione Medici Endocrinologi) Endokrinológusok Orvosi Egyesülete (Olaszország); anti-TPO = thyreoidea-peroxidáz elleni antitest; ATA $=($ American Thyroid Association $)$ Amerikai Pajzsmirigy Egyesület; BI-RADS = (Breast Imaging Reporting and Data System) Emlő Képalkotó Leletezési Adatrendszer; BSRTC $=($ Bethesda System for Reporting Thyroid Cytopathology) Bethesda-rendszer a pajzsmirigy-citopatológia jelentésére; $\mathrm{CT}=$ (computed tomography) számítógépes tomográfia; EU-TIRADS = (European Thyroid Imaging and Reporting Data System) Európai Pajzsmirigy Képalkotó Leletezési Adatrendszer; FAP = familiaris adenomatosus polyposis; FDG = fluoro-dezoxi-glükóz; FNAB = (fine-needle aspiration biopsy) vékonytü-aspirációs citológia; K-TIRADS $=($ Korean Thyroid Imaging and Reporting Data System) Koreai Pajzsmirigy Képalkotó Leletezési Adatrendszer; $\mathrm{HU}=$ (Hounsfield unit) Hounsfield-egység; $\mathrm{MEN}=$ multiplex endokrin neoplasia; $\mathrm{MRI}=$ (magnetic resonance imaging) mágnesesrezonancia-képalkotás; NGS = (next-generation sequencing) újgenerációs szekvenálás; PET = pozitronemissziós tomográfia; TG = thyreoglobulin; TRAK = (TSH-Rezeptor-Antikörper) TSHreceptor elleni antitest; $\mathrm{TSH}=$ (thyroid-stimulating hormone) pajzsmirigy-stimuláló hormon

A népesség széles körében fordul elő a pajzsmirigy göbös vagy cystosus megbetegedése. Az elmúlt időben megemelkedett a más indikációval végzett képalkotó vizsgálatok során véletlenül felismert, általában benignus és panaszt nem okozó pajzsmirigy-elváltozásoknak, az úgynevezett incidentalomáknak a száma $[1,2]$. Az incidentalomák 65\%-a ultrahanggal, 15\%-a CT-vel és MRvizsgálattal kerül felfedezésre, és mindössze $1-2 \%$-uk FDG-PET/CT segítségével [3]. Panaszmentes esetben is fontos ezen laesiók további vizsgálata, az esetleges malignitás esélyének meghatározása és az elváltozás követése. A kontrollvizsgálatok jelentős terhet rónak az egészségügyre, és a göbök mindössze 7-15\%-a mutat malignus transzformációt. Meg kell említeni továbbá a betegre nehezedő pszichés terhet, amit a kivizsgálás által okozott stressz jelenthet. Időben felismerve, a daganatok döntő hányada jó prognózisú [4].

A diagnózis felállításának alappillére az ultrahangvizsgálat, amely az elmúlt 60 év alatt dinamikus fejlődésen ment keresztül, és további távlatai még ismeretlenek. A pajzsmirigygöbök esetleges malignitásának ultrahangvizsgálattal történő megítélésére több kritériumrendszert is létrehoztak, azonban az ultrahanglelet önmagában ehhez nem elégséges. A pontos diagnózis eszköze a vékonytúl-aspirációs citológia (FNAB) és a mútéti prepa- rátum szövettani vizsgálata. Retrospektíve fontos minőségbiztosítási indikátor lehet a klinikai kórisme, az ultrahanglelet és a szövettani eredmény összevetése.

Célunk az, hogy összefoglaljuk az eddigi ismereteket, és rávilágítsunk a jövőben megválaszolandó kérdésekre. Cikkünk egy nagyobb kutatás első lépését képezi, melynek etikai engedélyszáma: 23/2020, Szegedi Tudományegyetem.

\section{Történeti áttekintés}

Az elmúlt közel 60 évben a pajzsmirigygöbök diagnosztikája robbanásszerú fejlődésen ment keresztül, az ultrahangdiagnosztika rohamos fejlődésének köszönhetően.

Az első cikket a témában Takano publikálta 1964-ben, ezt követően készült el az első pajzsmirigy-ultrahanglelet 1967-ben [5]. Az első képalkotó B-módban készült, az akkori technikához szükséges vízfürdóben. 1965 és 1970 között további 7 cikk jelent meg a témában [5], míg az elmúlt 5 évben ez a szám 6000 fölött van.

1971-ben a cysticus eltérések biztonsággal elkülöníthetővé váltak a szolid elváltozásoktól [6]. 1977-ben a FNAB elvégzésének szükségessége merült fel, amely a mai napig alkalmazott módszer a pajzsmirigy-diagnosztikában. Walfish és mtsai ajánlása alapján az ultrahangvizsgálat citológiai mintavétellel kiegészítve növeli az együttes diagnosztikai pontosságot, a citológiai eredményesség pedig fokozható a mintavétel ultrahangvezérelt elvégzésével [7].

Az 1980-as években újabb nagy ugrás történt a Doppler-vizsgálat térnyerésével, a készülékek alkalmassá váltak a véráramlás detektálására. A gócos elváltozások és a pajzsmirigylebenyek keringésének vizsgálata további információt nyújtott mind a radiológusok, mind a klinikusok számára.

Az első tudományos munka 1991-ben jelent meg Ophir és mtsai közlésében az elasztográfiáról [8], melyet 2005-ben alkalmaztak először a pajzsmirigy-diagnosztika területén.

\section{A képalkotó diagnosztikát megelőző lépések}

A kivizsgálás első lépése az anamnézisfelvétel és a fizikális vizsgálat. A göbök előfordulási gyakoriságáról pontos hazai adatok nem állnak rendelkezésre. A pajzsmirigygöbök prevalenciája tapintási lelet alapján 2-6\%, ultrahangvizsgálattal ez a szám 19-68\% és boncolási adatok alapján 8-65\% [9]. Az amerikai adatok alapján az incidencia 37000 fó évente, akiknél tapintható pajzsmirigygöböt fedeznek fel; ez a szám csaknem megduplázódott az elmúlt 30 évben [10]: ez megközelítőleg 16 millió embernél jelent tapintható göböt, az ultrahanggal felismert göbök száma ugyanakkora populáció esetén ezzel szemben 219 millió. Látható, hogy mennyivel nagyobb az ultrahanggal felismerhető göbök száma, ezért fontos, 
hogy a klinikailag releváns göböket elkülönítsük. A göbök körülbelül 95\%-a aszimptomatikus és 90\%-a benignus [3]. Jódhiányos területeken a populációban a tapintható göbök előfordulása $5 \%$, ez az adat azonban nemtől és kortól függ. A hajlamosító tényezők között előfordul a gyermekkori (fóként a fej-nyak régiót érintő) irradiáció, a pajzsmirigyrákra vonatkozó pozitív családi anamnézis, továbbá az örökletes szindrómák előfordulása (multiplex endokrin neoplasia-2 [MEN2], familiaris adenomatosus polyposis [FAP]) [11]. Rizikótényezőnek számítanak az autoimmun betegségek is, mint például a Hashimoto-thyreoiditis, valamint a citosztatikum-expozíció, melynek citosztatikus kezeléseket végző kórházi dolgozók vannak kitéve [12, 13].

A rizikófaktorok összefüggést mutatnak a szövettani típusokkal. A papillaris carcinoma gyakoribb a gyermekkori fej-nyak vagy egésztest-besugárzással kezelt betegek körében [14]. Emellett számos tanulmányban szignifikáns összefüggést találtak a papillaris carcinoma és a Hashimoto-thyreoiditis relatív rizikója között [12]. A pozitív családi anamnézis (szindrómához kötött [MEN2, FAP] vagy attól független esetekben) összefüggést mutat - differenciáltsági foktól függetlenül a pajzsmirigy-carcinomával és a medullaris carcinomával [14]. A MEN2A-szindrómás betegeknél gyakorlatilag minden esetben (több mint 90\%-ban) megjelenik medullaris pajzsmirigy-carcinoma, sốt a szindróma első manifesztációja általában maga a medullaris pajzsmirigycarcinoma, amely a leggyakrabban 5 és 25 éves életkor között jelentkezik [15]. MEN2B esetén a medullaris pajzsmirigy-carcinoma korán, akár már a csecsemőkorban kialakul, és jellegzetesen agresszív lefolyású.

A göbös átalakulás általában aszimptomatikus. Panaszok esetén a tünetek közé tartozik a gombócérzés, a dysphagia, a nyelészavar (általában akkor, ha a göb nagyobb, mint $3 \mathrm{~cm}$, és a nyelőcső közelében helyezkedik el), a dysphonia és a fájdalom. Nyelészavar a szimptomatikus páciensek között nagyjából 67\%-ban fordul elő [3].

A TSH-szint meghatározása a pajzsmirigy múködéséről ad felvilágosítást. Az anti-TPO-, TRAK-, TG-, antiTG- és kalcitoninmérés a pajzsmirigybetegség hátterét vizsgálja. Pajzsmirigy-túlmúködés és göbös golyva együttes jelenlétekor pajzsmirigy-szcintigráfiás vizsgálattal igazolható az autoimmun adenoma.

A TSH-szint meghatározása az első a laborvizsgálatok közül [11]. Célja kiszűrni a hiperfunkciót mutató diffúz vagy göbös pajzsmirigybetegségeket (a göbök kevesebb mint 5\%-a) [16]. Amennyiben a TSH-szint alacsony, a szabad $\mathrm{T}_{3^{-}}, \mathrm{T}_{4}$-szint magas, úgy radionukleotid-vizsgálat elvégzése javasolt, melynek során a fokális dúsítás keresése a cél. Ehhez a leggyakrabban használt radiofarmakon a ${ }^{99} \mathrm{TcO}_{4}$ ( ${ }^{99 \mathrm{~m}} \mathrm{Tc}$-pertechnetát), melynek $159 \mathrm{KeV}$ kibocsátott gamma-sugárzása jól leképezhet, 6 órás felezési ideje elfogadható. Farmakológiailag egy jódanalóg, így a pajzsmirigysejtekbe a jódhoz hasonló módon a nátriumjodid szimporteren, egy transzmembrán fehérjén keresztül jut be [17].

\section{Képalkotó vizsgálatok}

Az ultrahangvizsgálat kulcsfontosságú a pajzsmirigy képalkotásában, hiszen könnyen hozzáférhető, nem invazív, költséghatékony, továbbá a szerv felszíni elhelyezkedése miatt kiválóan alkalmas a méret, az alapszerkezet és a vascularisatio vizsgálatára. Hátránya azonban, hogy vizsgálófüggő módszer, azaz a vizsgálati eredményt jelentősen befolyásolja a vizsgálatot végző személy tapasztalata [18]. A vizsgálathoz magas frekvenciájú lineáris transzducert alkalmazunk, amely nagy felbontást biztosít, továbbá megfelelő irányítást ad a FNAB-mintavételhez [19]. Minden göb esetén ajánlott a Grant és mtsai által kidolgozott ultrahangkarakterizációs lexikon szerinti jellemzést alkalmazni, amely leírja az összetételt, az echogenitást, az alakot, a méretet, a határokat [20].

Az első ultrahangvizsgálat célja a felismert göbök jellemzése aszerint, hogy a látott göb mutat-e malignitásra utaló jegyeket; ezáltal meghatározzuk, hogy szükséges-e FNAB végzése. A látott összes göbből történő mintavétel túlzott és felesleges lenne, továbbá számos felesleges mütéthez vezetne $[17,18]$. Az ultrahangvizsgálatok során a populáció 19-68\%-a esetén találunk göböt a pajzsmirigyben, ezen göbök megközelítőleg 10\%-a malignus [9]. A malignus göbökben észlelt daganatok fó szövettani típusai: papillaris $(88 \%)$, follicularis carcinoma $(8 \%)$, lymphoma $(4 \%)$, medullaris (1\%) vagy anaplasticus (1\%) carcinoma [21].

Lymphomák esetén döntő hányadban non-Hodgkinlymphoma áll a háttérben. A legfóképpen érintett populáció az idősebb nők. A lymphomák jellegzetes tünete a gyors növekedés; gyakran krónikus lymphocytás thyreoiditis (krónikus Hashimoto-thyreoiditis) talaján alakulnak ki, mely normális hormonális statusszal vagy hypothyreosissal jár. Jellegzetes ultrahangmorfológiai megjelenése a hipoechogén terület, mely lobulált kontúrú, rosszul körülhatárolható, valamint cystosus részeket is tartalmaz [22].

A Bethesda-rendszert a pajzsmirigygöbök vizsgálatának és ellátásának multidiszciplináris voltát figyelembe véve hozták létre. Ez a klasszifikációs rendszer jelentősen megkönnyíti a kommunikációt a patológusok, endokrinológusok, radiológusok és sebészek között, egyfajta egységes nemzetközi nyelvként szolgál, ezáltal elősegíti a nemzetközi együttmúködéseket és az összehasonlíthatóságot [23].

A FNAB-minták diagnózisainak a BSRTC (2017) szerint ajánlott 6 kategóriája: I. nem diagnosztikus, illetve nem reprezentatív - ilyenkor újabb mintavétel szükséges; II. benignus - fizikális vizsgálattal, illetve ultrahangvizsgálattal való követés javasolt; III. atípusos - megfontolandó a molekuláris vizsgálat; IV. follicularis neoplasma vagy annak gyanúja - a göb eltávolítása javasolt; V. malignitásgyanús; és VI. malignus. Minden kategóriához egy feltételezett malignitási kockázat társítható, amely 0-3\% a benignus kategóriában és gyakorlatilag 100\% a malignus kategória esetén [24]. 
Jelenleg egyetlen olyan ultrahangmorfológiai jellemző sem ismert, amely önmagában megfelelő biztonsággal definiálná, hogy a látott göb malignus vagy sem [18]. Brito és mtsai a kutatásuk során 31 centrum metaanalízisének eredményeként 18288 göböt vizsgáltak, amelyek 20\%-a volt malignus [25]. Kutatásuk során arra jutottak, hogy a „taller-than-wide” ( magasabb, mint szélesebb”) megjelenés és a mikrokalcifikáció gyakori és szenzitív jellemzők, önmagukban azonban nem specifikusak a malignus göbökre. A jóindulatú göbök jellemző megjelenése a szivacsos szerkezet vagy az egyszerú cysticus megjelenés. Eredményeik alapján a göbök mérete szignifikáns összefüggést nem mutat a malignitás rizikójával [25]. Hasonló eredményre jutottak Smayra és mtsai: eredményeik alapján a göb mérete nem mutat kapcsolatot a Bethesda-pontszámmal [19]. Bethesda III. és IV. pontszám esetén szignifikánsan több volt az echószegény göb, továbbá a göb 'stiffness' értéke (tömörsége) elasztográfiás vizsgálatok során erős korrelációt mutatott a Bethesda-pontrendszerrel [19].

A pajzsmirigy vizsgálata során is alkalmazható a colorDoppler-vizsgálat, önmagában azonban ez sem ad pontos információt a pajzsmirigyben talált eltérés dignitásáról. A jól differenciált pajzsmirigy-carcinomák jól erezettek, a neoangiogenesis következtében. Ezzel szemben a gyorsan növő anaplasticus carcinomák hipovaszkularizáltak a környezetükhöz képest, a gyors növekedés következtében kialakuló necrosis miatt [22].

A pajzsmirigygöbök esetében megkülönböztetünk perifériás vascularisatiót („halo” jel), mely körbeveszi a göböt - ez általában benignus megjelenés -, valamint a vascularisatiónak azt a formáját, amikor az erek a göbön keresztül, intranodularisan futnak: ez általában a malignus eltérésekre jellegzetes. Az intranodularis erezettség - mikrokalcifikációval és a pajzsmirigygöböt körbevevő "halo" nélkül - malignus folyamatra utal [22].

Alkalmazhatunk kontrasztanyagos ultrahangvizsgálatot a microvascularisatio feltérképezésére, mely segít a dignitás megítélésében [26]. Alapelv, hogy a tumorszövet növekedésének egyik alapfeltétele a neoangiogenesis. A vizsgálat során kén-hexafluorid mikrogömböket (2-10 $\mu \mathrm{m})$ juttatunk intravénás úton a keringésbe. A transzducert a vizsgált lebenyre helyezzük, és a keringéssel a vizsgálati területre érkező kontrasztanyag kirajzolja a mikrocirkulációt. Malignitásra jellemző mintázat a kisfokú halmozás, amelyet a gyors növekedés következtében létrejövő necrosis okoz. Az inhomogén halmozás is a malignitás mellett szól, mert a keletkező erek aberránsak vagy örvényszerúek, ami a kontrasztanyag nem egyenletes eloszlását okozza a göbben. Benignus göbökre jellemző a homogén vagy gyưrüszerű halmozás [26].

Tekintettel arra, hogy olyan egyértelmû morfológiai jel sincs, amely biztosan jelezné a malignus göböt, igény fogalmazódott meg arra, hogy klasszikus mintázatfelismerési módszert alkalmazzunk a göbök jellemzése esetén, továbbá hogy elkerüljük a felesleges és egyre gyako- ribb negatív biopsziák számának további emelkedését [27].

2009-ben Horvath és mtsai kidolgozták a TIRADSrendszert: ez egy hatpontos skála a rosszindulatúság megítélésére, amely skálán egyre fokozódik a malignitási rizikó [28]. Az 1-es kategóriába normális, eltérés nélküli pajzsmirigylebenyek tartoznak (TIRADS 1.). A TIRADS 2 . csoportba minden benignus pajzsmirigyeltérés beletartozik. A 3-as kategóriába a feltehetően jóindulatú göbök tartoznak. A gyanús göbök megítélése a 4-es kategóriában kezdődik el. A 4a kategóriában a malignitás rizikója $5-10 \%$, a 4 b kategóriában $10-80 \%$ a malignitási rizikó. A TIRADS 5. kategóriába a feltehetően malignus göbök sorolódnak, a rizikó nagyobb, mint 80\%. A TIRADS 6. csoportban pedig a korábban FNAB-vel igazolt rosszindulatú göbök tartoznak [28].

Hasonló alapon, de eltérő megközelítést alkalmaztak 2011-ben Kwak és mtsai [27]. Az általuk kidolgozott rendszer, csakúgy, mint a chilei munkacsoporté, hasonló a mammográfiában alkalmazott BI-RADS rendszerhez, a klinikus és a radiológus közötti kommunikáció megkönynyítését is szolgálja. Megközelítésük Horvath és munkatársaihoz képest abban tér el, hogy kevesebb kategóriát alkalmaznak, ami egyszerüsíti az osztályozást, és csökkentheti a diagnosztikus eltérést a vizsgáló személyek között. A göbök jellemzése során a malignitásra utaló jelek megegyeznek a TIRADS és az EU-TIRADS esetén alkalmazottakkal. 2016-ban a Korean Society of Thyroid Radiology publikálta irányelvük frissítését, az addig megszerzett információk alapján. Az így létrehozott K-TIRADS rendszer a többihez hasonlóan az ultrahangmorfológiai vizsgálat alapján csoportosítja a göböket. Szempontrendszerük megkülönböztet magas, közepes és alacsony malignitásra gyanús göböket és benignus göböket. Ez a kritériumrendszer sem integrálja azonban a vascularisatio vizsgálatát és az elasztográfiai adatokat. K-TIRADS 1-es kategória esetén a pajzsmirigyben nem találunk göböt. A 2-es kategória estén benignus göbról beszélhetünk, mely szivacsos szerkezetú (2/B ábra), részlegesen vagy teljesen cysticus, üstököscsóva („comet tail”) müterméket ad B-módú képen. A K-TIRADS 3-as göb cystosus részeket is tartalmaz, szolid komponense izoechogén vagy echódús, és a három meghatározott, magas rizikójú jellemzőt nem foglalja magában (mikrokalcifikáció, spikulált vagy lobulált határ, „taller-thanwide" megjelenés). A K-TIRADS 4-es csoportba azok a göbök tartoznak, amelyek izoechogének vagy echódúsak, de nem tartalmazzák a magas rizikójú eltéréseket, továbbá szolidak, echószegények, és tartalmazzák a fent említett három gyanús morfológiai eltérést. A legnagyobb rizikójú göbök (K-TIRADS 5.) szolidak, echószegények, és tartalmaznak mikrokalcifikációt, craniocaudalis és laterolateralis átmérőjük eltérő, továbbá szabálytalan határúak. Aspirációs citológiai vizsgálat eltérő méret alapján indikált, K-TIRADS 2. esetén $2 \mathrm{~cm}$ felett, K-TIRADS 3 . esetén 1,5 cm felett, K-TIRADS 4-es és 5-ös kategória esetén $1 \mathrm{~cm}$ felett [29]. 


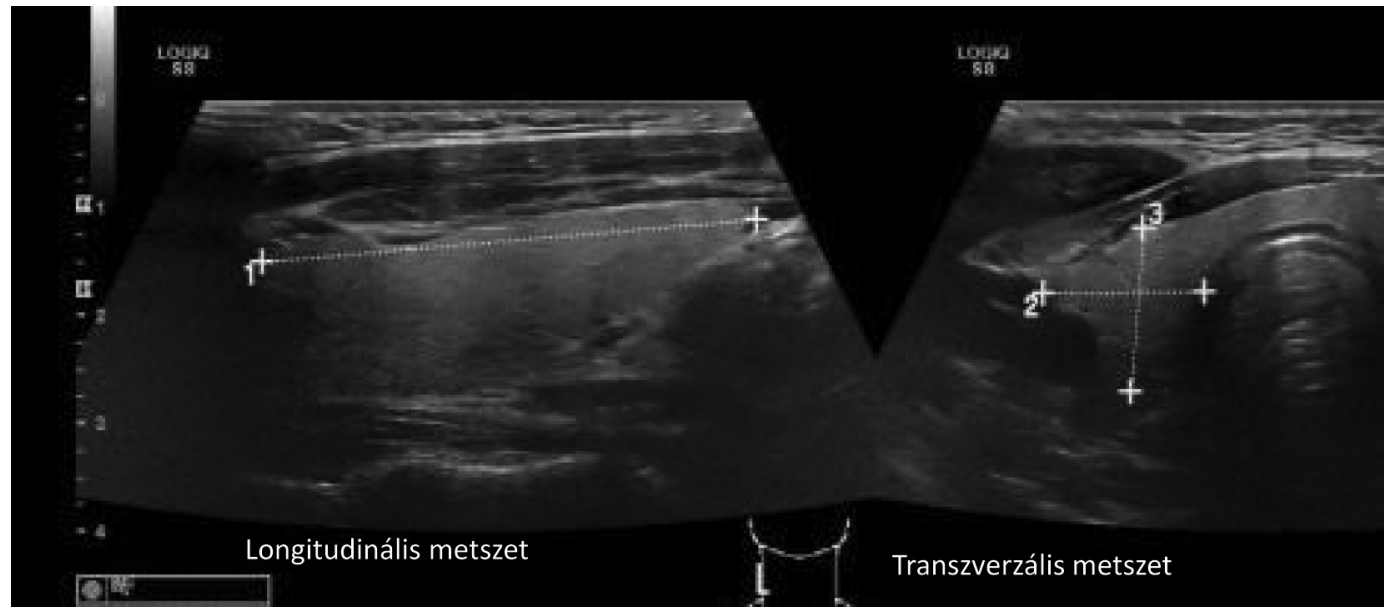

Az American College of Radiology 2017-ben létrehozta az ACR-TIRADS kritériumrendszert, amely pontrendszer alapján sorolja a göböket kategóriákba [30]. A pontrendszer alapja ebben a rendszerben is a göbök ultrahangmorfológiai megjelenése. Az összpontszám alapján TR 1. és TR 5. közötti kategóriákat különböztet meg. Az első pontozási kategóriában az összetétel 0 pont, ha döntő részben vagy egészben cysticus vagy szivacsos szerkezetû́ a göb. l ponttal értékeli a kevert típusú szolid göböket, a teljesen szolid göbök esetén 2 pontot kell adni. A második kritérium az echogenitás: 0 pontot kapnak az echómentes, l pontot az echódús vagy izoechogén, 2 pontot az echószegény és 3 pontot a szubjektíven kifejezetten echószegény göbök. A harmadik pontszám az alakra adható, mely 0 pont, ha a szélesség nagyobb a magasságnál, és 3 pont, ha craniocaudalis átmérője nagyobb a laterolateralis átmérőnél („taller-thanwide"). A göb a határai alapján 0 pontos, ha szabályos határokkal rendelkezik, 2 pontos, ha szabálytalan, és 3 pontos, ha pajzsmirigyen kívüli terjedés is detektálható. A következő pontszám a göbben látható eltérő echogenitású góc: 0 pont, ha nem tartalmaz vagy „üstököscsóva” mútermék látható, 1 pont a makrokalcifikáció, 2 pont a perifériás kalcifikáció és 3 pont a mikrokalcifikáció.

Szintén 2017-ben a TIRADS kritériumrendszer továbbfejlesztésére az Európai Pajzsmirigy Társaság megalkotta az EU-TIRADS (European Thyroid Imaging and Reporting Data System) rendszert, hogy minél kevesebb jellemző alapján meghozható döntés szülessen, így tovább csökkenjen az interobszerver variabilitás [18]. Az EU-TIRADS kritériumrendszer definiálja a benignus, az alacsony, közepes és magas malignitási rizikójú göböket, továbbá meghatározza, mikor van szükség FNAB-re.

Az Európai Pajzsmirigy Társaság a strukturált és standardizált leletezés szükségességét hangsúlyozza, és ajánlást bocsátott ki a lelet felépítésére [18]. Az ajánlás szerint a leletnek tartalmaznia kell a technikai adatokat

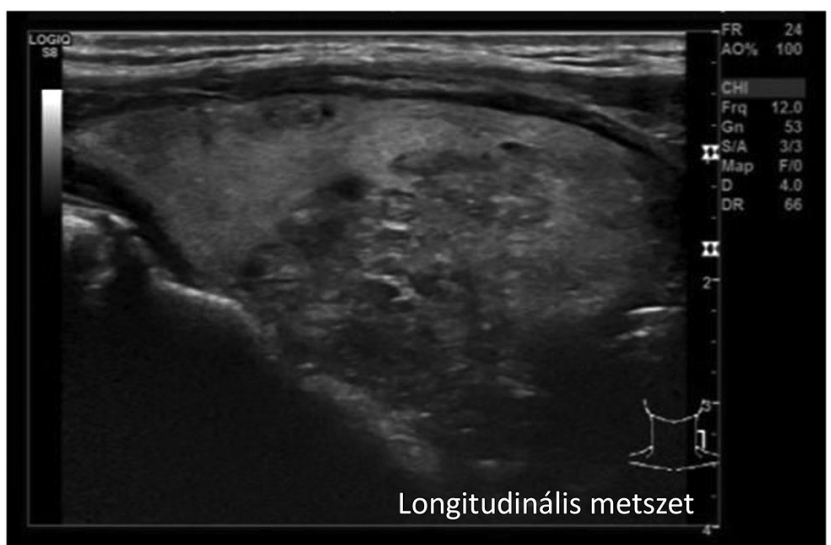

A

2. ábra

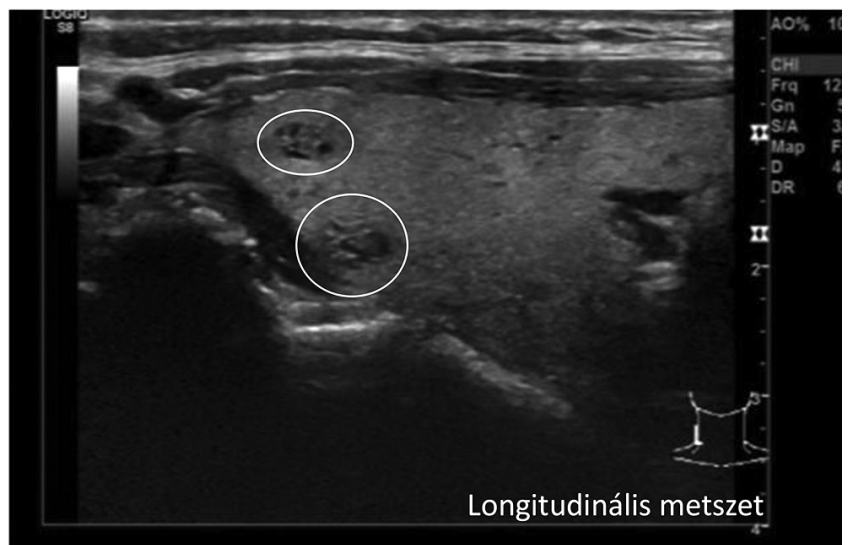

B

Egy 62 éves nőbeteg, hormonális eltérése nincs, rendszeresen jár kontrollvizsgálatokra. A pajzsmirigyben több különböző göb látható. A bal lebeny alsó részében inhomogén, környezeténél echószegényebb, rosszul körülhatárolt terület van, az EU-TIRADS besorolása szerint 4 . kategória, $1 \mathrm{~cm}$ felett mintavételt javasol (A). Mintavétel, majd mútéti eltávolítás történt. A jobb lebeny felső pólusában szivacsos szerkezetủ göbök, az alsó pólusban cystosus jellegú göbök is vannak, melyek nem bírnak klinikai relevanciával: EU-TIRADS 2. kategória (B)

EU-TIRADS = Európai Pajzsmirigy Képalkotó Leletezési Adatrendszer 
(a transzducer és az ultrahanggép típusa). Fel kell tüntetni a fontosabb anamnesztikus adatokat, többek között: családi anamnézis, korábbi operáció vagy FNAB-eredmény. A vizsgálat alatt rögzíteni kell a pajzsmirigylebenyek térfogatait, méreteit, az isthmus szélességét, a lebenyek echogenitását és vascularisatióját. A göbökre vonatkozóan az 5 mm-nél nagyobb vagy gyanús göböket kell a leletben jellemezni. A göb tekintetében meg kell adni az elhelyezkedést, három átmérőt, az alakot, a határokat és a göb echogenitását, és fel kell tüntetni a göb EU-TIRADS szerinti kategóriáját. A nyaki nyirokcsomók megjelenéséról is véleményt kell alkotni. Kontrollvizsgálat esetén nyilatkozni kell a méretváltozásról, az esetleges retrosternalis kiterjedésről. A „vélemény” részben a FNAB szükségességéről kell nyilatkozni [18].

Az EU-TIRADS rendszer 5 kategóriát különböztet meg a pajzsmirigygöbök csoportosítása során [18]. Az EU-TIRADS 1. kategóriában a vizsgált pajzsmirigyben nem látható göbös elváltozás (1. ábra).

Az EU-TIRADS 2. kategóriában a göbök valószínűleg nem malignusak. Két jellemző mintázatot láthatunk a csoportban: az egyik az egyszerú cysta, amely vékony septumokat tartalmazhat, azonban szolid belső növedék nem figyelhető meg; a másik a szivacsos megjelenésú göb (kis cystosus részeket tartalmazó göb), melynek mérete bármekkora lehet $(2 / B$ ábra, 3. ábra- metszet).

Az EU-TIRADS 3. kategóriában a göböknek alacsony, 2-4\%-nyi malignitási rizikójuk van. Az ebbe a csoportba tartozó göbök oválisak, éles határúak, izoechogének vagy echódúsak, továbbá nem mutatnak magas rizikóra utaló jeleket. Az ajánlás szerint akkor végzendő FNAB, ha a göb mérete nagyobb, mint $20 \mathrm{~mm}$. Az alsó határt azért határozták meg $20 \mathrm{~mm}$-nél, mert $20 \mathrm{~mm}$ alatt

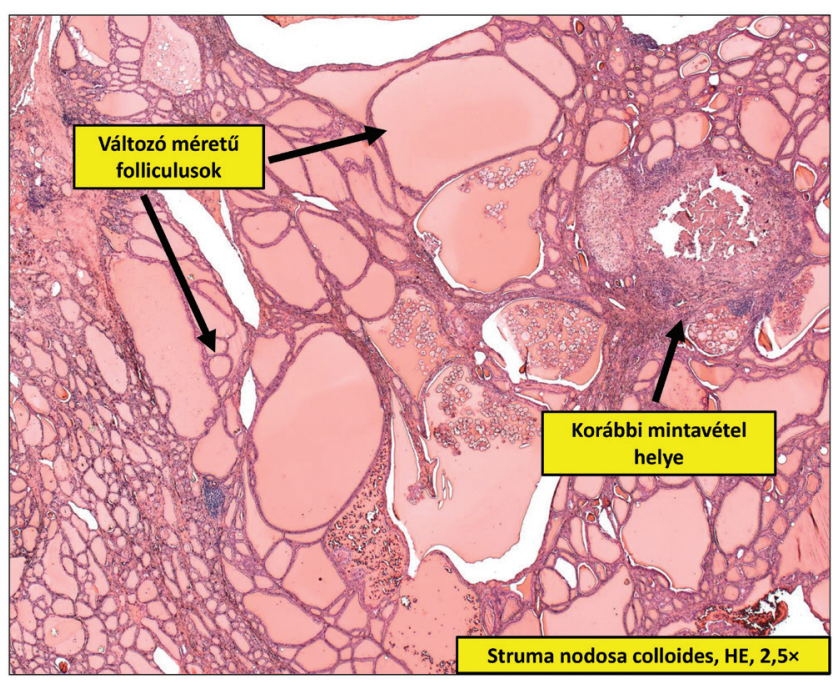

3. ábra

(metszet) Mikroszkóposan változó méretű folliculusokból felépülő pajzsmirigyet észleltünk. A korábbi mintavétel körül kialakult makrofágreakciót nyíl jelöli. Nagy nagyításon habos plaz májú makrofágok tûntek szembe (nyíl). A látott kép degeneratí jeleket mutató struma nodosának felelt meg

$\mathrm{HE}=$ hematoxilin-eozin

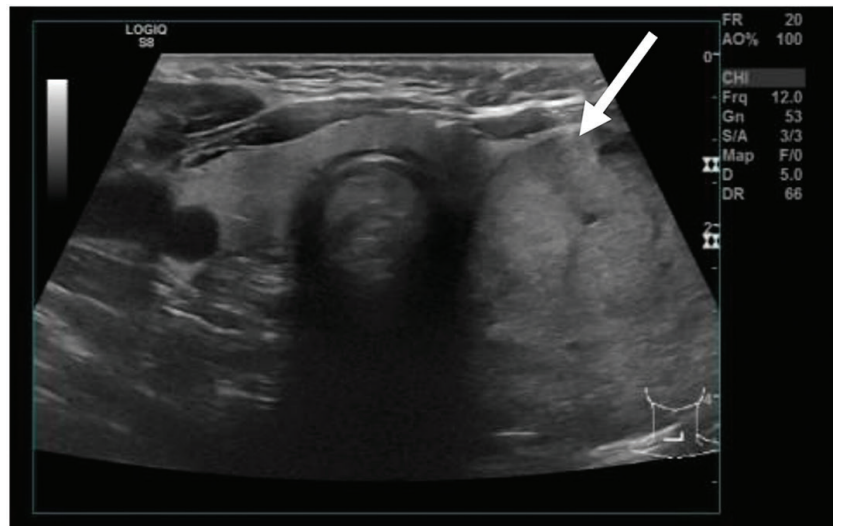

A

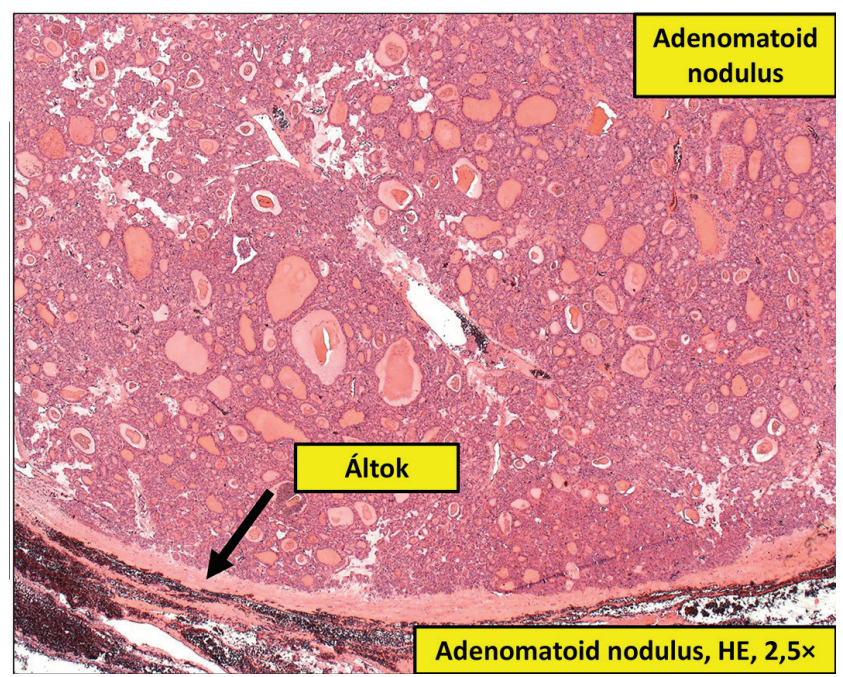

$\mathrm{B}$

4. ábra

Egy 45 éves férfi beteg, aki ambulancián a nyak bal oldalán észlelt aszimmetria miatt jelentkezett. Az ultrahangvizsgálat során jól látható, hogy a pajzsmirigy bal lebenyét egy nagy göb szélesíti ki. Az endokrinológiai kivizsgálás hormoneltérést nem talált. Az EU-TIRADS szerinti besorolás: 3. kategória, mely $20 \mathrm{~mm}$ felett aspirációs citológiai vizsgálatot javasol. Mivel az eltérés a $3 \mathrm{~cm}$-t is meghaladta, mintavétele megtörtént, majd a göb sebészi eltávolításra került (A). Szövettani metszeteken áltokkal (nyíl) övezett adenomatoid nodulus mutatkozott hyperplasiás thyreocytákkal (B)

EU-TIRADS = Európai Pajzsmirigy Képalkotó Leletezési Adat rendszer; $\mathrm{HE}=$ hematoxilin-eozin

ritkán alakul ki távoli metastasis follicularis tumor esetén [19] (4. ábra).

A közepes malignitásrizikójú csoport az EU-TIRADS 4. kategória, melyben a rizikó 6-17\%. A göbök oválisak, éles határral rendelkeznek, echószegények, ám nem mutatnak malignitásra utaló jellemzőket. FNAB akkor ajánlott, ha a göb nagyobb, mint $15 \mathrm{~mm}$. A 2-es és a 3-as kategória a göb echogenitásában különbözik. További jelek, melyek a malignitás rizikóját csökkentik: „üstököscsóva" mütermék, perifériás vascularisatio, vékony „halo” jel, továbbá alacsony „stiffness” érték az elasztográfia során (2/A ábra, 5. ábra).

A magas rizikójú kategóriába (EU-TIRADS 5.) azon göbök tartoznak, amelyek echószegények, mikrokalcifi- 


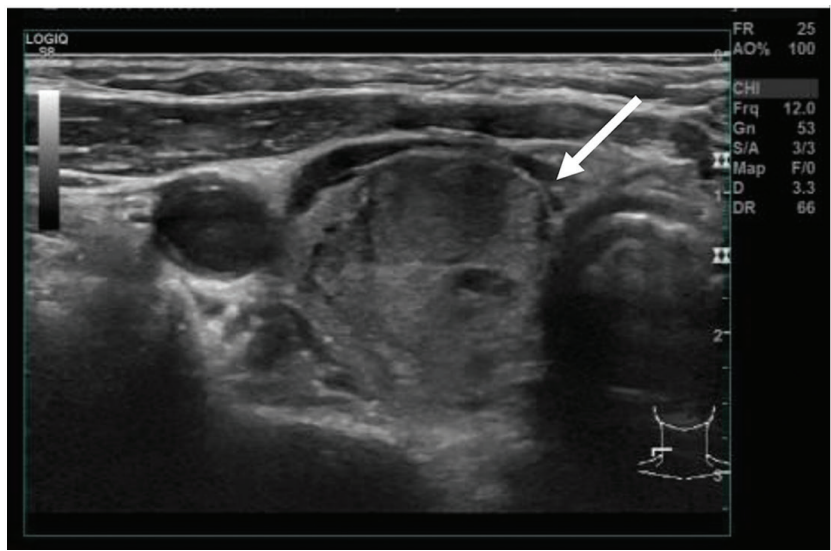

A

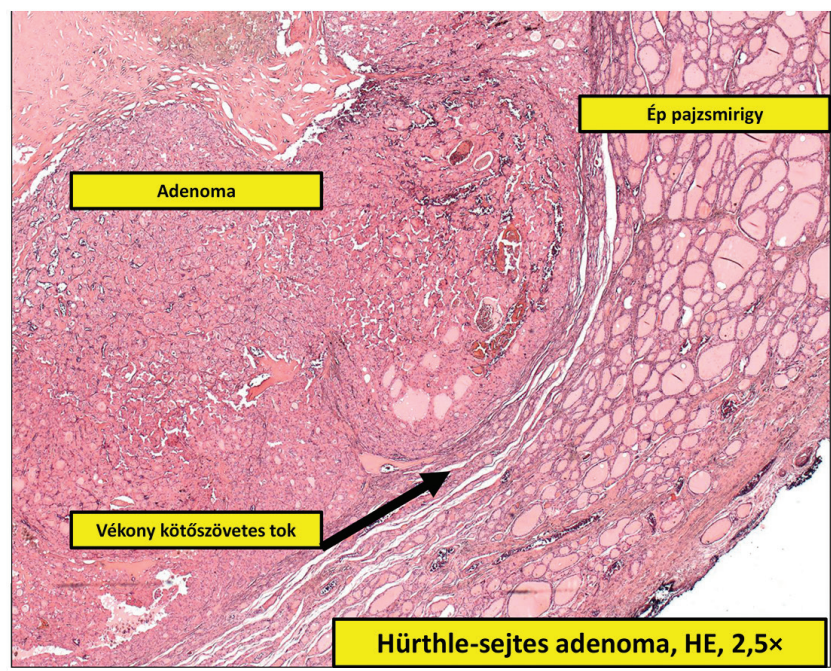

B

5. ábra

72 éves nőbeteg, pajzsmirigybetegsége régóta ismert, gyógy szert nem szed, a TSH rendben. Ultrahangvizsgálatra rendszeresen jár, a jobb lebenyben lévő göb az előző vizsgálathoz képest növekedést mutat. EU-TIRADS szerinti besorolása: 4. kategória. Szintén mintavétel, majd mútéti eltávolítás történ (A). A szövettani vizsgálat során vékony kötőszövetes tokkal határolt (nyíl), finoman granulált eosinophil citoplazmájú sejtproliferációt észleltünk, amely Hürthle-sejtes adenomának felelt $\operatorname{meg}(\mathrm{B})$

EU-TIRADS $=$ Európai Pajzsmirigy Képalkotó Leletezési Adatrendszer; $\mathrm{HE}=$ hematoxilin-eozin; $\mathrm{TSH}=$ pajzsmirigy-stimulá ló hormon

kációt tartalmaznak, nem oválisak, irreguláris vagy lobulált a határuk (6. ábra). Ezen jellemzők magas specificitásúak $(83,84 \%)$, de szenzitivitásuk alacsony (26-59\%) [31]. Citológiai vizsgálat akkor szükséges, ha a göb nagyobb, mint $10 \mathrm{~mm}$; ismétlés szükséges három hónap múlva negativitás esetén. Rebiopsziára azért van szükség, mert az igazolt álnegatív ráta FNAB esetén $0,7-11 \%$ [32]. Egyes szerzők azonban megkérdőjelezik a rebiopszia létjogosultságát, mivel ritka esetben tartalmaz többletinformációt, azonban felesleges megterhelés a páciensnek [33].

Az 1. táblázatból látható, hogy mindegyik kritériumrendszer mérôszámai magasak $[26,34]$. Az eddigi kutatások alapján, melyek az alkalmazhatóságot vizsgálták, az
EU-TIRADS kritériumrendszer esetén a vizsgált mérőszámok külön-külön nem a legmagasabbak, azonban mind a négy érték kiemelkedő megbízhatóságra utal. Ezért érdemes lehet ennek a kritériumrendszernek a használata hazánk populációja esetén is. A 2. táblázatban összesítve látható, hogy az egyes kritériumrendszerek mikor ajánlanak citológiai mintavételt a vizsgált göbökből.

Az első ultrahangvizsgálatot követően és a szükség szerint elvégzett FNAB után, a malignitás rizikója alapján, ultrahangos kontrollvizsgálatok javasoltak. A klinikus számára problémát jelenthet az evidenciákon alapuló utánkövetési protokoll alkalmazása [35]. Az ATA (American Thyroid Association) jelenleg akkor ajánl rebiopsziát, ha a göbök méretében szignifikáns növekedés észlelhető (a növekedés nagyobb, mint 20\%, vagy két átméróben nagyobb a növekedés, mint $2 \mathrm{~mm}$ ) [2]. Durante és mtsai kutatása alapján azonban aszimptomatikus beteg esetén az ultrahangmorfológia és a citológiailag benignus göbök nem mutattak szignifikáns méretnövekedést az 5 éves utánkövetési idő alatt, és a pajzsmirigyrák kialakulása ritka volt [2]. Javaslatuk alapján a kérdéskört további vizsgálatokkal kellene egységesíteni.

A biopsziák ismétlésére nincs megfelelő konszenzus. Su Min Ha és mtsai kutatása alapján, amennyiben a kezdeti vizsgálatkor a FNAB negatív eredményt mutatott, és a malignitás kockázata kisebb, mint $30 \%$ a K-TIRADS és TIRADS rendszerek alapján, elégséges egy biopsziát végezni [36].

\section{Egyéb képalkotó modalitások szerepe}

A pajzsmirigygöbök diagnosztikájában az ultrahangvizsgálat primer képalkotó eljárás, azonban a CT és az MRI szerepe sem elhanyagolható. Megjelenhet incidentalomaként vagy ismeretlen eredetû nyaki terime diagnosztikája esetén [10].

1. táblázat A négy ismertetett kritériumrendszer mérőszámainak összehasonlítása $[26,50]$

\begin{tabular}{lcccc}
\hline Jellemző & TIRADS & K-TIRADS & ACR-TIRADS & EU-TIRADS \\
\hline $\begin{array}{l}\text { Szenzitivitás } \\
(\%)\end{array}$ & 88 & $\begin{array}{c}71,4 \\
(68,5-74,2)\end{array}$ & $\begin{array}{c}96,6 \\
(95,3-97,6)\end{array}$ & $\begin{array}{c}83,2 \\
(80,7-85,9)\end{array}$ \\
\hline $\begin{array}{l}\text { Specificitás } \\
(\%)\end{array}$ & 49 & $\begin{array}{c}87,4 \\
(85,6-89,1)\end{array}$ & $\begin{array}{c}52,9 \\
(50,3-55,5)\end{array}$ & $\begin{array}{c}79,4 \\
(77,2-81,4)\end{array}$ \\
\hline PPV* (\%) $^{*} 49$ & $\begin{array}{c}79,6 \\
(76,8-82,2)\end{array}$ & $\begin{array}{c}58,6 \\
(56,1-60,9)\end{array}$ & $\begin{array}{c}73,5 \\
(70,9-76,1)\end{array}$ \\
\hline NPV* * $\%)^{2}$ & 88 & $\begin{array}{c}81,6 \\
(79,6-83,5)\end{array}$ & $\begin{array}{c}95,8 \\
(94,2-97,1)\end{array}$ & $\begin{array}{c}87,3 \\
(85,4-89,0)\end{array}$ \\
\hline
\end{tabular}

*PPV: pozitív prediktív érték (positive predictive value)

**NPV: negatív prediktív érték (negative predictive value)

ACR-TIRADS = Amerikai Radiológiai Kollégium - Pajzsmirigy Képalkotó Leletezési Adatrendszer; EU-TIRADS = Európai Pajzsmirigy Képalkotó Leletezési Adatrendszer; K-TIRADS = Koreai Pajzsmirigy Képalkotó Leletezési Adatrendszer; TIRADS = Pajzsmirigy Képalkotó Leletezési Adatrendszer 


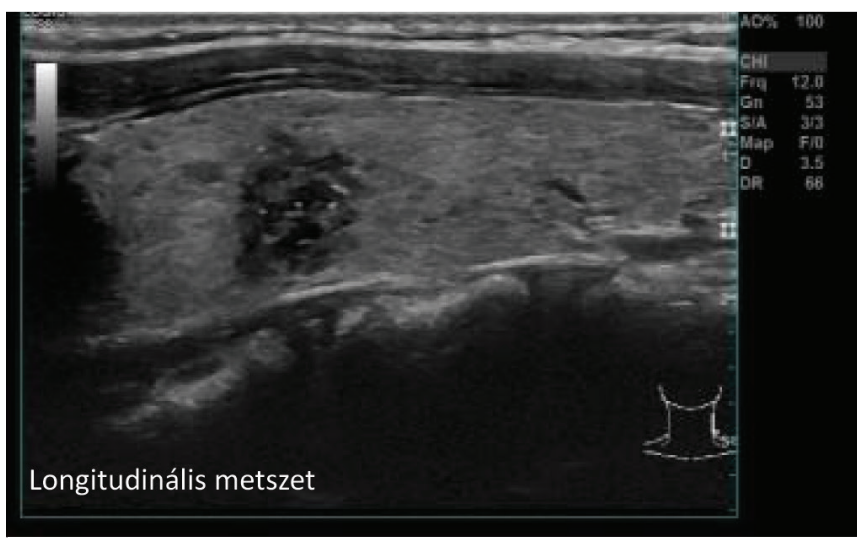

A

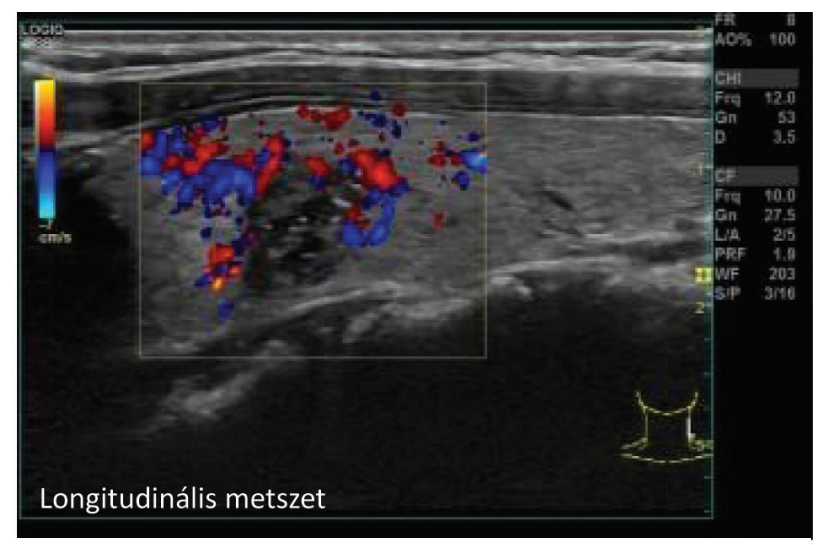

$\mathrm{B}$

6. ábra

\begin{abstract}
Egy 49 éves panaszmentes nóbeteg háziorvosi beutalóval érkezik, rutinvérvétel során észlelt magasabb TSH-érték miatt. A bal lebenyben jól látható egy $9 \mathrm{~mm}$ legnagyobb átmérőjű, rosszul körülhatárolt, echószegény mikromeszesedéseket is tartalmazó eltérés, mely az EU-TIRADS szerinti 5. kategóriába sorolható a megjelenése alapján. A malignitás lehetőségét az aspirációs citológia megerősítette, a pajzsmirigy eltávolítása megtörtént; a szövettani diagnózis papillaris konvencionális típusú carcinoma (pTla) lett Hashimoto-thyreoiditist támogató környezetben. A beteg a mútét után ablatív radiojód-kezelésben részesült

EU-TIRADS = Európai Pajzsmirigy Képalkotó Leletezési Adatrendszer; TSH = pajzsmirigy-stimuláló hormon
\end{abstract}

A CT-vizsgálat - mint kiegészítő képalkotás - különösen hasznos a nyaki régióban lévő lipoma esetén, mivel az hasonlíthat pajzsmirigygöbre, elsősorban akkor, ha az elváltozás körbefogja a pajzsmirigyet, vagy annak állományába benő. ultrahangvizsgálat során a zsírszöveti infiltrációk és zsírtömegek izoechogének lehetnek, így elkülönítésük a normálpajzsmirigytől nehézségekbe ütközhet, míg a CT-vizsgálat során a zsírszövetre jellemző negatív denzitás (-30 és -40 közötti HU) informatív lehet [12].

Ismert pajzsmirigy-carcinoma esetén a vizsgálatokat megelőzően a radiológus és a klinikus kommunikációja ajánlott, hiszen a CT-vizsgálatok esetén alkalmazott kontrasztanyag jódtartalmú. Ezekben az esetekben a kontrasztanyag adása kerülendő, mert a jódterhelés 6-8 hétig befolyásolhatja a pajzsmirigy jódfelvételét. Kezeletlen hyperthyreosisban thyreotoxicus krízist okozhat, amely hónapokra lehetetlenné teszi a pajzsmirigy funkci- onális vizsgálatát. Továbbá carcinoma esetén, differenciáltsági foktól függetlenül, a szcintigráfia a mútét utáni radiojód-ablatiót késleltetheti 2-6 hónappal, intézeti protokolltól függően [37].

Differenciált pajzsmirigyrákok esetén a mütét utáni kezelés részeként az ablatív radiojód-kezelés alkalmas a pajzsmirigy remnant, inoperábilis vagy nem teljesen eltávolított daganat, továbbá a képalkotó módszerekkel még nem detektálható differenciált pajzsmirigyrák szelektív besugárzására. Abszolút kontraindikációja a terhesség és a szoptatás. A terápiához szájon át adva, páciensre szabott dózisban, a jód 131-es izotópját használjuk (fizikai felezési idő 8,06 nap), mely átlagosan $364 \mathrm{KeV}$ energiájú béta-sugárzást bocsát ki: ez a környezetében lévő anyag tulajdonságaitól függően 0,6-2 mm-re hatol, és kifejti roncsoló hatását. A terápia előtt a TSH-szint megemelése szükséges $(\geq 30 \mathrm{mU} / \mathrm{l})$ annak érdekében, hogy a nátrium-jodid szimporter expressziója a sejtek felületén

2. táblázat |A kritériumrendszerek ajánlása a mintavételi mérethatárokra

\begin{tabular}{|c|c|c|c|c|c|c|c|}
\hline \multicolumn{2}{|l|}{ TIRADS } & \multicolumn{2}{|c|}{ K-TIRADS } & \multicolumn{2}{|c|}{ ACR-TIRADS } & \multicolumn{2}{|c|}{ EU-TIRADS } \\
\hline Kategória & Mérethatár (mm) & Kategória & Mérethatár (mm) & Kategória & Mérethatár (mm) & Kategória & Mérethatár $(\mathrm{mm})$ \\
\hline TIRADS 1. & \multirow{6}{*}{$\begin{array}{l}\text { Nem tartalmaz } \\
\text { mérethatárra } \\
\text { vonatkozó } \\
\text { megkötést }\end{array}$} & K-TIRADS 1. & - & TR 1. & - & EU-TIRADS 1. & - \\
\hline TIRADS 2. & & K-TIRADS 2. & $>20 \mathrm{~mm}$ & TR 2. & - & EU-TIRADS 2. & - \\
\hline TIRADS 3. & & K-TIRADS 3. & $>15 \mathrm{~mm}$ & TR 3. & $>25 \mathrm{~mm}$ & EU-TIRADS 3. & $>20 \mathrm{~mm}$ \\
\hline TIRADS $4 \mathrm{a}$ & & K-TIRADS 4. & $>10 \mathrm{~mm}$ & TR 4. & $>15 \mathrm{~mm}$ & EU-TIRADS 4. & $>15 \mathrm{~mm}$ \\
\hline TIRADS $4 b$ & & K-TIRADS 5. & $>10 \mathrm{~mm}$ & TR 5. & $>10 \mathrm{~mm}$ & EU-TIRADS 5. & $>10 \mathrm{~mm}$ \\
\hline TIRADS 5. & & & & & & & \\
\hline TIRADS 6. & $\begin{array}{l}\text { Korábbi FNAB } \\
\text { által igazolt göb }\end{array}$ & & & & & & \\
\hline
\end{tabular}

ACR-TIRADS = Amerikai Radiológiai Kollégium - Pajzsmirigy Képalkotó Leletezési Adatrendszer; EU-TIRADS = Európai Pajzsmirigy Képalkotó Leletezési Adatrendszer; FNAB = vékonytü-aspirációs biopszia; K-TIRADS = Koreai Pajzsmirigy Képalkotó Leletezési Adatrendszer; TIRADS = Pajzsmirigy Képalkotó Leletezési Adatrendszer 
megnövekedjen, ezzel a szervezetben maradó differenciált pajzsmirigyráksejtekben, -szövetekben a radiojód-felvétel növekedjen [37].

MRI esetén a kontrasztanyag nem befolyásolja a pajzsmirigy múködését, mert nem jódtartalmú, hanem gadolíniumot tartalmaz. Nyaki MRI során a diffúziósúlyozott felvételek többletinformációt tartalmazhatnak, mert a jóindulatú göbök magasabb diffúziós együtthatóval rendelkeznek, mint a malignus göbök, ám a képalkotás alappillére továbbra is az ultrahangvizsgálat [38].

Arra vonatkozóan, hogy hogyan leletezzük a pajzsmirigyben talált incidentalomákat, jelenleg nincs egységes irányelv. A leggyakrabban alkalmazott módszer, hogy 10 mm feletti göbök esetén kell további ultrahangvizsgálatot ajánlani [39]. Az így indikált ultrahangvizsgálatokkal értékelt göbök 78\%-a benignus [40]. Hoang és mtsai kidolgoztak egy stratégiát a metszeti képalkotó vizsgálatok során felismert incidentalomák kategorizálására, amelyet később módosítottak [41]. Három fókategóriát hoztak létre; az 1. kategória a magas malignitási gyanú: PET/CT vizsgálat során dúsító göb, pajzsmirigyen kívüli terjedés, nyirokcsomó-megnagyobbodás vagy tüdőmetastasis látható. Ezekben az esetekben FNAB ajánlott. A 2. kategóriába a közepes fokú malignitási rizikójú göbök tartoznak, malignitási rizikófaktorokkal (pozitív családi anamnézis, 20 évnél fiatalabb női páciens vagy 35 évnél fiatalabb férfi páciens), ez esetben ultrahangvizsgálat javasolt. A 3. kategória hasonló, azonban nincsenek malignitási rizikófaktorok. Ebben az esetben a $10 \mathrm{~mm}$ nél nagyobb göböket kell a leletben feltüntetni. Eredményeik alapján a szükséges ultrahangvizsgálatok száma a felére csökkent, a malignus folyamatok felismerésének változatlan effektivitása mellett [42].

A metszeti képalkotó vizsgálatok további szerepe a nyirokcsomó- és a távoli metastasisok kimutatásában, valamint a környező szervek infiltrációjának felismerésében van. Follicularis carcinoma esetén ritka, papillaris és medullaris szövettani típusúak esetén gyakori a nyaki nyirokcsomó-metastasis. Véletlenül felfedezett patológiás nyirokcsomó esetén, primer tumorkeresés során, minden pajzsmirigygöb további vizsgálata javasolt és gyanúsnak tekintendő $[17,18]$. Igazolt pajzsmirigy-malignitás esetén nyirokcsomóstaging szükséges.

A benignus, reaktív nyirokcsomók ovális alakúak, centrális echódús hilusuk van. Malignus nyirokcsomók esetén a hilus nem azonosítható, lehetnek csökkent echogenitásúak; bennük cystosus részek vagy mikrokalcifikáció is megfigyelhető, ezek kifejezetten jellegzetesek a papillaris és a medullaris pajzsmirigyrákokra [22]. Elvesztik ovális alakjukat, ami jellemezhető a rövid átméró növekedésével vagy a Steinkamp-aránnyal (hosszú átmérő/rövid átmérő); malignitásra gyanús, ha ez az arány 2 alatt van [43]. A 3. táblázatban a nyaki nyirokcsomók regionális felosztásának határai láthatók, továbbá a malignitásra utaló rövid átmérőértékek. A nyirokcsomó-régiók felosztásakor a fej-nyaki tumorok terjedésének figyelembevétele és a társszakmák kommunikációjának megkönnyítése volt a cél [44]. Fontos a preoperatív vizsgálatok során a nyirokcsomók pontos értékelése, mert észre nem vett nyirokcsomók esetén a sebészi kezelés elégtelen lehet, és a páciensnek újabb mütéteken kell átesnie [44]. A nyirokcsomóáttétek gyakori helye a VI.

3. táblázat |A nyaki nyirokcsomó-régiók elhelyezkedése, a malignitásra utaló rövid átméróhatárok

\begin{tabular}{|c|c|c|c|c|c|}
\hline \multicolumn{6}{|c|}{ Határok } \\
\hline $\begin{array}{l}\text { Nyirokcsomó- } \\
\text { régió }\end{array}$ & Superior & Inferior & Anterior/medialis & Posterior/lateralis & $\begin{array}{l}\text { Malignitásra utaló } \\
\text { rövid átmérő }(\mathrm{mm})\end{array}$ \\
\hline IA & Mandibula & Nyelvcsont & $\begin{array}{l}\text { Az ellenoldali m. digastri- } \\
\text { cus elülső hasa }\end{array}$ & $\begin{array}{l}\text { Az azonos oldali } \mathrm{m} . \\
\text { digastricus elülső hasa }\end{array}$ & $>10 \mathrm{~mm}$ \\
\hline IB & Mandibula & Nyelvcsont & A m. digastricus elülső hasa & M. stylohyoideus & \\
\hline IIA & Koponyaalap & $\begin{array}{l}\text { A nyelvcsont } \\
\text { testének alsó széle }\end{array}$ & M. stylohyoideus & N. spinalis accessorius & $>8 \mathrm{~mm}$ \\
\hline IIB & Koponyaalap & $\begin{array}{l}\text { A nyelvcsont } \\
\text { testének alsó széle }\end{array}$ & N. spinalis accessorius & $\begin{array}{l}\text { A m. sternocleidomasto- } \\
\text { ideus lateralis határa }\end{array}$ & \\
\hline III. & $\begin{array}{l}\text { A nyelvcsont testének } \\
\text { alsó széle }\end{array}$ & $\begin{array}{l}\text { A cartilago } \\
\text { cricoidea alsó } \\
\text { határa }\end{array}$ & $\begin{array}{l}\text { A m. sternohyoideus } \\
\text { lateralis határa }\end{array}$ & $\begin{array}{l}\text { A m. sternocleidomasto- } \\
\text { ideus lateralis határa }\end{array}$ & $>5 \mathrm{~mm}$ \\
\hline IV. & $\begin{array}{l}\text { A cartilago cricoidea } \\
\text { alsó határa }\end{array}$ & Clavicula & $\begin{array}{l}\text { A m. sternohyoideus } \\
\text { lateralis határa }\end{array}$ & $\begin{array}{l}\text { A m. sternocleidomasto- } \\
\text { ideus lateralis határa }\end{array}$ & \\
\hline VA & $\begin{array}{l}\text { A m. sternocleidomas- } \\
\text { toideus és a m. trapezius } \\
\text { csúcsa }\end{array}$ & $\begin{array}{l}\text { A cartilago } \\
\text { cricoidea alsó } \\
\text { határa }\end{array}$ & $\begin{array}{l}\text { A m. sternocleidomasto- } \\
\text { ideus hátsó határa }\end{array}$ & $\begin{array}{l}\text { A m. trapezius elülső } \\
\text { határa }\end{array}$ & $>10 \mathrm{~mm}$ \\
\hline $\mathrm{VB}$ & $\begin{array}{l}\text { A cartilago cricoidea } \\
\text { alsó határa }\end{array}$ & Clavicula & $\begin{array}{l}\text { A m. sternocleidomasto- } \\
\text { ideus hátsó határa }\end{array}$ & $\begin{array}{l}\text { A m. trapezius elülső } \\
\text { határa }\end{array}$ & \\
\hline VI. & Nyelvcsont & Suprasternalis régió & $\mathrm{Az}$ a. carotis communis & $\mathrm{Az}$ a. carotis communis & $>5 \mathrm{~mm}$ \\
\hline
\end{tabular}

a. $=$ arteria $;$ m. = musculus; $\mathrm{n} .=$ nervus 
régió és a lateralis nyirokcsomócsoportok (II-IV.) [45]. A pajzsmirigy-carcinoma propagációja szempontjából kiemelt figyelmet kell fordítani az alsó paratrachealis nyirokcsomókra, valamint a felsô mediastinumban (VII.), retropharyngealisan és retrooesophagealisan elhelyezkedő nyirokcsomókra [10].

Összefoglalva, a metszeti képalkotó vizsgálatok során jelentős mennyiségú információ gyújthető a pajzsmirigygöbökről, alkalmasak a nyirokcsomóstatus megítélésére, továbbá a mútéti tervezésben is lehet szerepük, a göbök pontos karakterizálására azonban továbbra is az ultrahang a választandó vizsgálat.

\section{A jövő lehetőségei}

A palpáció standard diagnosztikai technika. A tapintott, kemény pajzsmirigygöb felveti a malignitás lehetőségét, a vizsgálat azonban szubjektív, és függ a vizsgáló személy tapasztalatától, továbbá a gyanús göbök nagyságától és elhelyezkedésétől. A pajzsmirigygöbök vizsgálatában élénken kutatott vizsgálómódszer az elasztográfia. Az elasztográfiára hivatkozhatunk úgy, mint „electronic palpation” [46]. A technika segítségével reprodukálható információt kapunk a szöveti tömörségről („stiffness”: ellenállás, tömörség).

A módszer lényege, hogy az energiaközlés hatására (kompresszió) létrejövő deformáció ismeretében következtethetünk a vizsgált terület „stiffness”-ére. Két fo" módszer ismert, az egyik típus a deformációs szonoelasztográfia („strain elastographia”). Ez az eljárás az energiaközlés hatására létrejövő deformitás mértékét detektálja egy színskála, azaz elasztogram segítségével. „Shearwave" elasztográfia esetén az alakváltozás hatására létrejövő nyíráshullámok sebességét mérjük [47]. A vizsgálathoz ugyanazt a transzducert és ultrahangkészüléket alkalmazzuk, mint standard vizsgálat esetén. A pajzsmirigy-diagnosztika terén a „strain” elasztográfia használatával van több tapasztalat. Az elasztogram a B-módú képen jeleníti meg színskála formájában az „elasticity score”-t. Benignus göb esetén ez l-2 pont, a malignus göbök az esetek döntő többségében 3-4 ponttal rendelkeznek [22].

A szövetek tömörségét a strukturális mátrix tulajdonságai határozzák meg. Gyulladásos vagy malignus folyamatok esetén megváltozik a szöveti összetétel, és e strukturális változások fokozzák ezt az értéket [46].

A jelenlegi kutatások kiegészítő információként tekintenek az elasztográfiára, nem önálló metódusként [47]. Az American Association of Clinical Endocrinologists, az American College of Endocrinology és az Associazione Medici Endocrinologi (AACE/ACE/AME) irányelvei alapján az elasztográfia kiegészítő információt nyújt a B-módú képekhez, kifejezetten a közepes rizikójú göbök esetén [17].

Bojunga és mtsai 639 göbre kiterjedő metaanalízist végeztek; ennek alapján a „strain” elasztográfia szenzitivitása $92 \%$, specificitása $90 \%$ a malignitás meghatározására vonatkozóan, míg ezen értékek „shear-wave” elasztográ- fia esetén $80 \%$ és $85 \%$ [48]. 2012-ben egy további vizsgálat a konvencionális ultrahangvizsgálat és az elasztográfia kombinációjának közös szenzitivitását 97\%-osnak mérte, negatív prediktív értéke pedig szintén 97\% volt. A szerző́k azonban megemlítették, hogy számít a vizsgálatot végző orvos tapasztalata [9]. Ezen adatok alapján további vizsgálatok szükségesek a módszer biztonságos alkalmazásához, azonban az eddigi eredmények biztatóak és pontosabbak csupán az említett kritériumrendszerek alkalmazásánál.

Az elasztográfia használata mellett a mesterséges intelligencia (artificial intelligence, AI) - és munkamódszere, a "deep learning” (mélytanulás) - témakörének kutatása is megjelent a pajzsmirigygöbök diagnosztikájában, az eredmények pedig ezen a területen is biztatóak. Több kutatás is született már a témában, ám a kis elemszám és a retrospektív vizsgálati modell limitálja jelenleg az ismereteinket. Hazánkban is megjelent már olyan eszköz, amely alkalmaz AI-t pajzsmirigyvizsgálatok esetén. A pajzsmirigy kifejezetten alkalmas szerv AI-t alkalmazó kutatásokra, hiszen felületes elhelyezkedése miatt könynyü reprezentatív felvételeket készíteni. Az eddigi eredményeket azonban korlátozza, hogy a vizsgálatok során a radiológiai lelethez viszonyították a rendszerek teljesítményét, és nem a citológiai eredményhez. Song és mtsai retrospektív kutatásuk során olyan göböket vizsgáltak, melyek esetén FNAB is történt. Mesterséges neuronhálózatuk tréninghalmaza több mint 1,2 millió képboól állt. A folyamat során a vizsgálni kívánt tulajdonságokat a tréninghalmaz elemzésekor a neuronhálózat kivonja a képekból, és kategorizálja azokat egy algoritmus segítségével. Ezt követően 1358 göb ultrahangfelvételét elemeztették kutatásuk során, és az algoritmus döntött, hogy az adott göb benignus vagy malignus, osztályozta a göböket a K-TIRADS kategóriái szerint. Vizsgálati eredményeik ígéretesek, a szenzitivitást 95,2\%-osnak, a negatív prediktív értéket 95,5\%-osnak, míg a specificitást 94\%-osnak mérték [49].

Wildman-Tobriner és mtsai AI (AI-TIRADS: Artificial Intelligence - Thyroid Imaging Reporting and Data System) alkalmazásával elemezték a göböket, és ezzel egy időben radiológusok az ACR-TIRADS kritériumrendszer használatával döntöttek a FNAB szükségességéról. Eredményeik alapján 100 göböt vizsgálva 15 olyan eset volt, amikor az AI nem ajánlott FNAB-t, a radiológus viszont igen. Mind a 15 esetben benignus göbról volt szó. Látható tehát, hogy - kis elemszámú minta alapján ugyan, de - magasabb szenzitivitás és kevesebb számú aspirációs citológiai vizsgálat érhetô el az AI alkalmazásával [50].

A fent említettek mellett az újgenerációs szekvenáláson (NGS) alapuló platformok további lehetóséget nyitnak a pajzsmirigygöbök diagnosztikájában: bizonytalan citológiai eredmények kiegészítésére, pontosítására ma már egyre inkább módot ad a FNAB során vett minta molekuláris diagnosztikai vizsgálata. Az NGS-platformok által vizsgálható genetikai információ mennyisége a 
korábbi metódushoz képest jelentősen nagyobb. Több gén teljes bázissorrendjének leolvasására képes, amelyeket bioinformatikai szoftverek és online adatbázisok segítségével elemezhetnek a szakemberek [34]. Segítségével számos, pajzsmirigyrákban ismert gén szomatikus eltéréseit is vizsgálhatjuk a mintavételt követően, ami fokozza az együttes diagnosztikai pontosságot.

\section{Következtetés}

Az elmúlt közel 60 évben a technológia, a képminőség, valamint a vizsgálati eszközök rohamos fejlődése figyelhető meg, így az ultrahang vált az elsőként választandó módszerré a pajzsmirigygöbök képalkotó vizsgálatában. Egyértelmű konszenzus a göbök jellemzésére és a malignitás biztos megállapítására nem született. A kritériumrendszerek lényegi szerepe a göbök kiválasztásában van, így csökkentve a felesleges aspirációs citológiai vizsgálatok számát és a megfelelő betegcsoport kiválasztását. $\mathrm{Az}$ eredmények alapján a négy ismertetett kritériumrendszernek külön-külön megvan a maga előnye: szenzitivitásuk és specificitásuk kisebb eltéréseket mutat. Területi vagy intézményi szinten érdemes egy bizonyos rendszert választani és azt követve megkönnyíteni a klinikus és a radiológus közös munkáját. Az ismertetett eredmények alapján az EU-TIRADS rendszert jellemzi a legmagasabb specificitási és szenzitivitási mutató, ezek alapján Magyarországon érdemes lehet e mellett a kritériumrendszer mellett dönteni.

Egyelőre nincs meghatározott diagnosztikai stratégia a göbök utánkövetésének gyakoriságára. Szükséges lenne azonban egységes szemlélet kialakítása ezen a téren is, a növekvő incidencia és a relatíve alacsony malignus transzformáció ismeretében, továbbá az epidemiológiai adatgyuujtés és a magyarországi adatok elemzése is hasznos információt nyújtana a hazai állapotok pontosabb megítélésére. Az elasztográfia jelenleg is számos kiegészítő információt biztosíthat egy-egy adott vizsgálat vagy göb esetén. A témában további kutatás szükséges a vizsgálattípus szerepének pontosításában és az alkalmazás szabályainak meghatározásában.

Ezen kutatásoknak szerepük lehet az interobszerver variabilitás csökkentésében, ezáltal tovább emelhetik a diagnosztikus biztonságot a pajzsmirigygöbök esetén.

Anyagi támogatás: A közlemény megírása anyagi támogatásban nem részesült.

Szerzői munkamegosztás: P. P.: A szempontok kidolgozása a képalkotás szemszögéből, szakirodalmi másodelemzés, adatgyưjités, a kézirat szövegezése. Z. T.: Szempontok kidolgozása a patológus szemszögéből, szakirodalmi másodelemzés, a kézirat szövegezése. K. L.: Szempontok kidolgozása a patológus szemszögéből, szakirodalmi másodelemzés. M. S.: Szempontok kidolgozása az endokrinológus szemszögéből, a kézirat szövegezése.
K. F.: Szakirodalmi másodelemzés, a kézirat szövegezése, rendszerezés. M. Z.: Az ultrahangos képalkotás szempontjainak felülvizsgálata. P. A.: kézirat szövegezése, a radiológiai szempontok felülvizsgálata. V. A.: Szempontok kidolgozása a patológus szemszögéből, szakirodalmi másodelemzés, a kézirat szövegezése. K. Zs. T. és F. Zs.: A kézirat szövegezése. A cikk végleges változatát valamennyi szerző elolvasta és jóváhagyta.

Érdekeltségek: A szerzőknek nincsenek érdekeltségeik.

\section{Irodalom}

[1] Russ G, Leboulleux S, Leenhardt L, et al. Thyroid incidentalomas: epidemiology, risk stratification with ultrasound and workup. Eur Thyroid J. 2014; 3: 154-163.

[2] Durante C, Costante G, Lucisano G, et al. The natural history of benign thyroid nodules. JAMA 2015; 313: 926-935.

[3] Durante C, Grani G, Lamartina L, et al. The diagnosis and management of thyroid nodules: a review. JAMA 2018; 319: 914924.

[4] Györi G, Kocsis-Deák B, Lakatos P. Ultrasound imaging of thyroid nodules. The up-to-date report. [A göbös pajzsmirigy ultrahangvizsgálata - a korszerú ultrahanglelet.] Magy Radiol Online 2018; 92: 11-21. [Hungarian]

[5] Levine RA. Something old and something new: a brief history of thyroid ultrasound technology. Endocr Pract. 2004; 10: 227233.

[6] Blum M, Weis B, Hernberg J. Evaluation of thyroid nodules by A-mode echoqraphy. Radiology 1971; 101: 651-656.

[7] Walfish PG, Hazani E, Strawbridge HT, et al. Combined ultra sound and needle aspiration cytology in the assessment and management of hypofunctioning thyroid nodule. Ann Intern Med. 1977; 87: 270-274.

[8] Ophir J, Céspedes I, Ponnekanti H, et al. Elastography: a quantitative method for imaging the elasticity of biological tissues. Ultrason Imaging 1991; 13: 111-134.

[9] Trimboli P, Guglielmi R, Monti S, et al. Ultrasound sensitivity for thyroid malignancy is increased by real-time elastography: a prospective multicenter study. J Clin Endocrinol Metab. 2012; 97: 4524-4530.

[10] Hoang JK, Branstetter BF 4th, Gafton AR, et al. Imaging of thyroid carcinoma with CT and MRI: approaches to common scenarios. Cancer Imaging 2013; 13: 128-139.

[11] Land CE, Kwon D, Hoffman FO, et al. Accounting for shared and unshared dosimetric uncertainties in the dose response for ultrasound-detected thyroid nodules after exposure to radioactive fallout. Radiat Res. 2015; 183: 159-173.

[12] Steiner T, Péter I, Pogány P, et al. Combined presentation of autoimmune thyroiditis, bilateral papillary thyroid carcinoma, cervical thyrolipoma and diabetes mellitus. [Az autoimmun thyreoiditis, a kétoldali papillaris pajzsmirigy-carcinoma, a nyaki thyreolipoma és a diabetes mellitus együttes előfordulása.] Orv Hetil. 2018; 159: 1024-1032. [Hungarian]

[13] Tompa A, Jakab M, Biró A, et al. Genetic and immune-toxicologic studies on abnormal thyroid functions in hospital employees exposed to cytostatic drugs. [Citosztatikus kezelést végző kórházi dolgozók pajzsmirigy-elváltozásainak géntoxikológiai és immuntoxikológiai vonatkozásai.] Orv Hetil. 2015; 156: 60-66. [Hungarian]

[14] Cooper DS, Doherty GM, Haugen BR, et al. Revised American Thyroid Association management guidelines for patients with thyroid nodules and differentiated thyroid cancer. Thyroid 2009; 19: 1167-1214. [Erratum: Haugen, BR. Thyroid 2010; 20: 942.] [Erratum: Haugen, BR. Thyroid 2010; 20: 674-675.] 
[15] Hircsu I, Gazdag A, Bodor M, et al. Multiple endocrine neoplasia type $2 \mathrm{~A}$ in a family. [A multiplex endokrin neoplasia-2A szindrómáról egy család kapcsán.] Orv Hetil. 2020; 161: 75-79. [Hungarian]

[16] Bomeli SR, LeBeau SO, Ferris RL. Evaluation of a thyroid nodule. Otolaryngol Clin North Am. 2010; 43: 229-238.

[17] Gharib H, Papini E, Garber JR, et al. American Association of Clinical Endocrinologists, American College of Endocrinology, and Associazione Medici Endocrinologi medical guidelines for clinical practice for the diagnosis and management of thyroid nodules - 2016 update. Endocr Pract. 2016; 22(Suppl 1): 622639.

[18] Russ G, Bonnema SJ, Erdogan MF, et al. European Thyroid Association Guidelines for ultrasound malignancy risk stratification of thyroid nodules in adults: the EU-TIRADS. Eur Thyroid J. 2017; 6: 225-237.

[19] Smayra T, Charara Z, Sleilaty G, et al. Classification and regression tree (CART) model of sonographic signs in predicting thyroid nodules malignancy. Eur J Radiol Open 2019; 6: 343-349.

[20] Grant EG, Tessler FN, Hoang JK, et al. Thyroid ultrasound reporting lexicon: white paper of the ACR Thyroid Imaging, Reporting and Data System (TIRADS) Committee. J Am Coll Radiol. 2015; 12: 1272-1279.

[21] Fagin JA, Mitsiades N. Molecular pathology of thyroid cancer: diagnostic and clinical implications. Best Pract Res Clin Endocrinol Metab. 2008; 22: 955-969.

[22] Rumack CM, Wilson SR, Charboneau JW, et al. (eds.) Diagnostic ultrasound, 4th edition. Elsevier-Mosby, Philadelphia, PA, 2014.

[23] Cibas ES, Ali SZ. The Bethesda System for Reporting Thyroid Cytopathology. Am J Clin Pathol. 2009; 132: 658-665.

[24] Cibas ES, Ali SZ. The 2017 Bethesda System for Reporting Thyroid Cytopathology. Thyroid 2017; 27: 1341-1346.

[25] Brito JP, Gionfriddo MR, Al Nofal A, et al. The accuracy of thyroid nodule ultrasound to predict thyroid cancer: systematic review and meta-analysis. J Clin Endocrinol Metab. 2014; 99: $1253-1263$

[26] Zhan J, Ding H. Application of contrast-enhanced ultrasound for evaluation of thyroid nodules. Ultrasonography 2018; 37: 288-297.

[27] Kwak JY, Han KH, Yoon JH, et al. Thyroid imaging reporting and data system for US features of nodules: a step in establishing better stratification of cancer risk. Radiology 2011; 260: 892899.

[28] Horvath E, Majlis S, Rossi R, et al. An ultrasonogram reporting system for thyroid nodules stratifying cancer risk for clinical management. J Clin Endocrinol Metab. 2009; 94: 1748-1751.

[29] Shin JH, Baek JH, Chung J, et al. Ultrasonography diagnosis and imaging-based management of thyroid nodules: revised Korean Society of Thyroid Radiology consensus statement and recommendations. Korean J Radiol. 2016; 17: 370-395.

[30] Xu T, Wu Y, Wu RX, et al. Validation and comparison of three newly-released thyroid imaging reporting and data systems for cancer risk determination. Endocrine 2019; 64: 299-307.

[31] Kim EK, Park CS, Chung WY, et al. New sonographic criteria for recommending fine-needle aspiration biopsy of nonpalpable solid nodules of the thyroid. Am J Roentgenol. 2002; 178: 687691.

[32] Wang CC, Friedman L, Kennedy GC, et al. A large multicenter correlation study of thyroid nodule cytopathology and histopathology. Thyroid 2011; 21: 243-251.

[33] Kessler A, Gavriel H, Zahav S, et al. Accuracy and consistency of fine-needle aspiration biopsy in the diagnosis and management of solitary thyroid nodules. Isr Med Assoc J. 2005; 7: 371-373.
[34] Kocsis-Deák B, Balla B, Árvai K, et al. Genetic testing of thyroid nodules using a gene panel developed on a new generation sequencing platform. [A pajzsmirigygöbök genetikai vizsgálata újgenerációs szekvenáláson alapuló platformon kifejlesztett génpanel segítségével.] Orv Hetil. 2019; 160: 1417-1425. [Hungarian]

[35] Filetti S, Durante C, Torlontano M. Nonsurgical approaches to the management of thyroid nodules. Nat Clin Pract Endocrinol Metab. 2006; 2: 384-394.

[36] Ha SM, Baek JH, Choi YJ, et al. Malignancy risk of initially benign thyroid nodules: validation with various thyroid imaging reporting and data system guidelines. Eur Radiol. 2019; 29: 133-140.

[37] van der Molen AJ, Thomsen HS, Morcos SK, et al. Effect of iodinated contrast media on thyroid function in adults. Eur Radiol. 2004; 14: 902-907.

[38] Razek AA, Sadek AG, Kombar OR, et al. Role of apparent diffusion coefficient values in differentiation between malignant and benign solitary thyroid nodules. Am J Neuroradiol. 2008; 29: 563-568.

[39] Johnson PT, Horton KM, Megibow AJ, et al. Common incidental findings on MDCT: survey of radiologist recommendations for patient management. J Am Coll Radiol. 2011; 8: 762-767.

[40] Yoon DY, Chang SK, Choi CS, et al. The prevalence and significance of incidental thyroid nodules identified on computed tomography. J Comput Assist Tomogr. 2008; 32: 810-815.

[41] Hoang JK, Raduazo P, Yousem DM, et al. What to do with incidental thyroid nodules on imaging? An approach for the radiologist. Semin Ultrasound CT MR 2012; 33: 150-157.

[42] Nguyen XV, Choudhury KR, Eastwood JD, et al. Incidental thyroid nodules on CT: evaluation of 2 risk-categorization methods for work-up of nodules. Am J Neuroradiol. 2013; 34: 18121817.

[43] Leenhardt L, Erdogan MF, Hegedús L, et al. 2013 European Thyroid Association guidelines for cervical ultrasound scan and ultrasound-guided techniques in the postoperative management of patients with thyroid cancer. Eur Thyroid J. 2013; 2: 147159.

[44] Kumbhar SS, O'Malley RB, Robinson TJ, et al. Why thyroid surgeons are frustrated with radiologists: lessons learned from preand postoperative US. Radiographics 2016; 36: 2141-2153.

[45] Nam IC, Park JO, Joo YH, et al. Pattern and predictive factors of regional lymph node metastasis in papillary thyroid carcinoma: a prospective study. Head Neck 2013; 35: 40-45.

[46] Zhao CK, Xu HX. Ultrasound elastography of the thyroid: principles and current status. Ultrasonography 2019; 38: 106-124.

[47] Fekete M, Erdei M, Dienes A, et al. Ultrasound elastographic examination of the thyroid gland: a twin study. [A pajzsmirigy ultrahang-elasztográfís vizsgálata ikreken.] Magy Radiol Online 2019; 93: 15-24. [Hungarian]

[48] Bojunga J, Herrmann E, Meyer G, et al. Real-time elastography for the differentiation of benign and malignant thyroid nodules: a meta-analysis. Thyroid 2010; 20: 1145-1150.

[49] Song J, Chai YJ, Masuoka H, et al. Ultrasound image analysis using deep learning algorithm for the diagnosis of thyroid nodules. Medicine (Baltimore) 2019; 98: el5133.

[50] Wildman-Tobriner B, Buda M, Hoang JK, et al. Using artificial intelligence to revise ACR TI-RADS risk stratification of thyroid nodules: diagnostic accuracy and utility. Radiology 2019; 292: 112-119.

(Fejes Zsuzsanna dr., Szeged, Semmelweis u. 6/A, 6725 e-mail: fejes.zsuzsanna02@szte.hu)

A cikk a Creative Commons Attribution 4.0 International License (https://creativecommons.org/licenses/by/4.0/) feltételei szerint publikált Open Access közlemény, melynek szellemében a cikk bármilyen médiumban szabadon felhasználható, megosztható és újraközölhetö, feltéve, hogy az eredeti szerző és a közlés helye, illetve a CC License linkje és az esetlegesen végrehajtott módosítások feltüntetésre kerülnek. (SID_1) 